\title{
The Effect of Adding Thyme Extracts on Microbiological, Chemical and Sensory Characteristics of Yogurt
}

\author{
Sarmad Ghazi Al-Shawi* (D), Haider Ibrahim Ali ${ }^{D}$ and Zena Kadhim Al-Younis \\ Food Science Department-Agriculture College-Basrah University, Iraq.
}

\begin{abstract}
This study evaluated the effects of adding alcoholic and aqueous extracts of thyme on microbiological, chemical and sensory characteristics of yogurt. Supplementation of yogurt with thyme extracts during storage time were found to influence on yogurt composition compared to plain yogurt. So, plain yogurt (PY), thyme alcoholic extract yogurt (TCEY) and thyme aqueous extract yogurt (TAEY) moisture

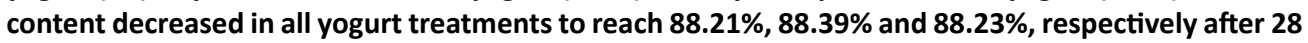
days of storage. Protein content increased after 28 days of storage and reached to $4.82 \%, 4.83 \%$ and $4.81 \%$, respectively. Fat content tended to increase at the end of study period to reach $0.32 \%, 0.36$ and $0.326 \%$ respectively. The ash percentage after 28 days of storage increased to reach $0.71 \%, 0.72 \%$ and $0.71 \%$, respectively. Titratable acidity increased after 28 day to $1.28,1.17$ and 1.2 while the pH decreased to $4.24,4.31$ and 4.29 respectively. For sensory evaluation, (TCEY) was more acceptable followed by (TAEY) and (PY) respectively. Microbial content revealed that all yogurt treatments were close at zero time for lactic acid bacteria (LAB) content and increased gradually to $(7.38,7.31$ and 7.32) $\log (\mathrm{cfu} / \mathrm{ml})$ respectively, there wasn't any grow during all study periods in (TCEY) and (TAEY) for coliform and yeast \& mold content, while there was a grow in (PY) after 14 day for coliform and after 21 day for yeast \& mold.
\end{abstract}

Keywords: Thyme, Yogurt, TCEY, TAEY, Sensory Characteristics

\footnotetext{
*Correspondence: sarmadghazi@yahoo.com

(Received: March 17, 2020; accepted: June 01, 2020)

Citation: Al-Shawi SG, Ali HI, Al-Younis ZK. The Effect of Adding Thyme Extracts on Microbiological, Chemical and Sensory Characteristics of Yogurt. J Pure Appl Microbiol. 2020;14(2):1367-1376. doi: 10.22207/JPAM.14.2.34

(C) The Author(s) 2020. Open Access. This article is distributed under the terms of the Creative Commons Attribution 4.0 International License which permits unrestricted use, sharing, distribution, and reproduction in any medium, provided you give appropriate credit to the original author(s) and the source, provide a link to the Creative Commons license, and indicate if changes were made.
} 


\section{INTRODUCTION}

Yogurt is a dairy product produced by fermenting the milk using Streptococcus thermophilus and Lactobacillus delbrueckii spp. bulgaricus. Yogurt production beginning was in the Middle East as fermented product and spread all over the world. The converting milk lactose during fermentation into lactic acid through yogurt bacteria which ferment lactose, will facilitate the consumption of yogurt for people with lactose intolerance without any side effects. Furthermore, yogurt consumption will lead to a slight reduction in the $\mathrm{pH}$ of the stomach which affect positively on reducing the risk of many diseases ( $O^{\prime}$ connell and Fox, 2001). As fermented milk products are widely-consumed food all over the world, these products used to deliver a good nutritional value to the human. Moreover, supplementing these fermented products such as yogurt with different nutritional additives would be a good way in improving nutrient intake in human daily food consumption (Preedy et al., 2013).

Thyme (Thymol vulgaris) is a famous herb belonging to the Labiatae family called the mint family (Mossa, 1987), native to the Mediterranean and the southern Europe and it is evergreen herb (Gillett, 1998). The thyme blooms from June to October, and its flowers are small, pink in the form of a spike with a pungent smell. Thyme has been used from the ancient times to add favor to meats, cheeses (Aygun et al., 2005; Akarca et al., 2016; Cornara et al., 2000).

Thyme not used just in foods, it is a well-known herbal medicine which was used to treat inflammatory skin disorders, dental plaque, alopecia, cough, bronchitis, and dermatophyte infections (Basch et al., 2004). Several laboratory studies have shown that thyme has shown anti-inflammatory, antifungal and antibacterial effects to many bacteria such as Salmonella spp. Escherichiacoli, Staphylococcus aureus (Dorman and Deans, 2000: Basch et al., 2004). Major essential oil components of Thyme vulgaris are thymol $(23 \%-60 \%)$, $y$-terpinene $(18 \%-50 \%)$, p-cymene $(8 \%-44 \%)$, carvacrol $(2 \%-8 \%)$, and linalool (3\%-4\%) (Duke, 1992). Many researchers reported that thyme volatile oils are one of the main essential oils used in food products and as antioxidants (Zarzuelo and Crespo, 2002).

There is increasing interest in using the natural ingredients in food preservation. The essential oils specifically have both the antimicrobial and the antioxidants properties. For example, the addition of oregano essential oil $(1 \% \mathrm{v} / \mathrm{w})$ into ground meat delayed the microbial growth (Skandamis and Nychas, 2001). While the addition of oregano essential oil to the fillets of beef meat contaminated with Listeria monocytogenes significantly affected on reducing bacteria counts (Tsigarida et al., 2000). The essential oil (Citrus) acted as an active antimicrobial agent when adding it to bread and dairy products (Salim et al., 2007; Gammariello et al., 2008).

Since yogurt has a limited antioxidant activity, many attempts have been conducted to fortify it with antioxidants from natural sources which represented a good impact and a new approach for yogurt development (Gahruie et al., 2015; Caleja et al., 2016). So, several plants' extracts such as herbs and fruits which have health-promoting properties such as antioxidant and antimicrobial effects are used as yogurt additives to improve its functional and nutritional value. Considerable types of functional food are currently available in the markets consist of herbal supplemented functional foods. An increase demand for natural antimicrobial substances alternatives to replace synthetic additives, and replacing it with herbal extracts in food products has attracted remarkable attention (Van Haute et al., 2016). Phytochemical antioxidants are abundant in herbs and spices, and the top five antioxidants out of 50 foods with antioxidants are dried spice (Carlsen et al., 2010)

The aim of this study was to investigate the effect of adding thyme extracts on microbiological, chemical and sensory characteristics of yogurt and subsequently on extending the shelf life of manufactured yogurt products.

\section{MATERIALS AND METHODS Thyme}

Was purchased from the local markets of Basrah city

\section{Aqueous extract}

The aqueous extract of thyme was prepared by using the Case (2005) modified method. $10 \mathrm{~g}$ of thyme was infused in $100 \mathrm{ml}$ of $\left(95^{\circ} \mathrm{C}\right)$ hot distilled water, left for overnight under refrigeration $\left(4^{\circ} \mathrm{C}\right)$. After $24 \mathrm{~h}$, the thyme extract 
was kept in rotary shaker at $100 \mathrm{rpm}$ for $1 \mathrm{~h}$, the extract filtered with filter paper (Whatman No.1) and then lyophilized at $-47.5^{\circ} \mathrm{C}$. The frozen thyme extract was then freeze-dried to a powder and stored at $4^{\circ} \mathrm{C}$.

\section{Alcoholic extract}

Alcoholic extract of thyme prepared according to Elmastas et al. (2015) with some modification, by adding $100 \mathrm{~g}$ of thyme to 500 $\mathrm{ml}$ of $100 \%$ ethyl alcohol and mixing well. The sample was placed in a vertical shaker at $30^{\circ} \mathrm{C}$ for 24 hours after which the extract was filtered using (Whatman No.1) filter paper. The filtrate then was concentrated by using rotary vacuum evaporator at $40^{\circ} \mathrm{C}$ to dispose of the solvent, then left at laboratory temperature until it gets dry and viscous, weighed and placed in dark sealed bottles and kept in the refrigerator until use.

Free fat skim milk powder (regilait)

Purchased from local market and used in manufacturing of yogurt.

\section{Starter cultures}

Starter culture was a 1:1 mixture of Streptococcus thermophiles and Lactobacillus bulgaricus (Chr. Hansen, Denmark).

Preparation of yogurt treatments

Yogurt treatments were produced as described by Güler-Akin (2005).About $600 \mathrm{~g}$ of skimmed powder milk reconstituted with water, heated (pasteurization) to $80^{\circ} \mathrm{C}$ for 15 minute, allowed to cool $\left(42-45^{\circ} \mathrm{C}\right)$ before inoculation with starter culture. The milk then distributed into three portions: plain yogurt (PY), $0.5 \% \mathrm{w} / \mathrm{w}$ thyme alcoholic extract yogurt (TCEY) and $0.5 \% \mathrm{w} / \mathrm{w}$ thyme aqueous extract yogurt (TAEY). They were inculpated at $43^{\circ} \mathrm{C}$ for $10-12 \mathrm{~h}$ until a pH (4.3-4.5) was attained. Yogurt treatments were kept at $\left(4^{\circ} \mathrm{C}\right)$ in a refrigerator during the study periods $(0,7,14$, 21 and 28 day).

\section{Chemical and physical tests of yogurt}

Moisture in yogurt was estimated according to A.O.A.C (2005). The ash was estimated by the direct burning method described in A.O.A.C (2008), the total nitrogen was estimated by using semi-micro Kjeldahl method as described by Uaboi-Egbenniet et al. (2010) by taking $0.2 \mathrm{~g}$ of the sample and digesting it using concentrated sulfuric acid, then it was distilled using Kjeldahl apparatus, after titration, the total protein ratio was calculated by multiplying the total nitrogen value in the coefficient 6.38 . The percentage of fat was estimated according to Egan et al. (1988). The titratable acidity was estimated according to A.O.A.C. (2008). The $\mathrm{pH}$ was estimated by placing a pH meter sensor directly into the yogurt sample. Microbial analyses

MRS agar was used to enumerate lactic acid bacteria (LAB). MacConkey agar was used for Coliform enumeration, Potato Dextrose Agar (PDA) was used for yeast and mold enumeration.

\section{Sensory Evaluation of Yogurt}

Sensory tests for the refrigerated yogurt treatments were carried out in the Food Science Department - College of Agriculture - University of Basrah by specialists in accordance with the sensory evaluation form developed by (Nelson and Trout, 1964) with some modifications by canceling the container score and adding it to acidity score. Statistical design and analysis

Completely Randomized Design (CRD) was used to analyze the data and the mean parameters were compared using the lowest significant LSD at 0.05 (SPSS, 2009).

\section{RESULTS AND DISCUSSION}

Table (1) shows the moisture content for plain yogurt (PY), thyme alcoholic extract yogurt (TCEY) and thyme aqueous extract yogurt (TAEY) treatments which were $(89 \%, 88.98 \%$ and $89 \%$, respectively). This result was identical to the findings of Ihemeje et al. (2015) who found that the moisture content for fat-free yogurt was $88.10 \%$, high moisture content attributed to the lack of total solids due to the reduction of fat in them, and this is consistent with Madadlou et al. (2005) who showed that fat reduction led to increase yogurt's moisture content. The high content of moisture in yogurt could be attributed to the reconstitution of the milk with water prior to fermentation (Ihemeje et al., 2015). The result was contrary to Hossain et al. (2012) who reported that moisture content of yogurt fortified with different kind of juices was $74.03 \%$. During the storage period, a decrease in yogurt moisture content was observed in all yogurt treatments to reach $88.21 \%$, $88.39 \%$ and $88.23 \%$, respectively after 28 days of storage, and this result agreed with Qureshi et al. (2011) who showed that yogurt moisture decreasing was from $84.78 \%$ to $84.65 \%$ during the storage period of 15 days, and this decrease may 
Table 1. Chemical compositions of plain yogurt, thyme alcoholic extract yogurt and thyme aqueous extract yogurt

\begin{tabular}{lllllll}
\hline & & \multicolumn{5}{c}{ Storage Periods (Day) } \\
\cline { 3 - 7 } Treatments & Ingredients \% & 0 & 7 & 14 & 21 & 28 \\
\hline \multirow{2}{*}{ Plain Yogurt } & Moisture & 89 & 88.97 & 88.84 & 88.56 & 88.21 \\
& Protein & 4.57 & 4.6 & 4.65 & 4.75 & 4.82 \\
& Fat & 0.178 & 0.194 & 0.214 & 0.27 & 0.32 \\
& Ash & 0.58 & 0.61 & 0.64 & 0.68 & 0.71 \\
Thyme alcoholic & Moisture & 88.98 & 88.87 & 88.74 & 88.51 & 88.39 \\
extract yogurt & Protein & 4.55 & 4.59 & 4.64 & 4.76 & 4.83 \\
& Fat & 0.184 & 0.2 & 0.225 & 0.31 & 0.36 \\
Thyme aqueous & Ash & 0.54 & 0.6 & 0.66 & 0.7 & 0.72 \\
extract yogurt & Moisture & 89 & 88.95 & 88.81 & 88.52 & 88.23 \\
& Protein & 4.58 & 4.62 & 4.67 & 4.75 & 4.81 \\
& Fat & 0.177 & 0.196 & 0.218 & 0.273 & 0.326 \\
\hline
\end{tabular}

LSD $=0.25(p<0.05)$

be due to the evaporation during storage or may resulted from the decrease in $\mathrm{pH}$.

The protein percentage of (PY), (TCEY) and (TAEY) was non-significant $(p<0.05)$ as shown in table (1) and it was $4.57 \%, 4.55 \%$ and $4.58 \%$, respectively. This result was close to Hossain et al. (2012) who found that protein content of yogurt fortified with different kind of juices was $3.50 \mathrm{~g}$ and less than the finding of Ihemeje et al. (2015) who found that protein content in flavored yogurts was $9.97 \%$. Results were in contrary with Tarakci and Kucukoner (2003) who found significant differences among protein content in fruit-flavored yoghurt samples. During the storage period, there was an increase in the percentage of protein in all yogurt treatments. The values after 28 days of storage were $4.82 \%, 4.83 \%$ and $4.81 \%$, respectively and without any significant differences $(p<0.05)$. The reason for this increase may be attributed to the continued decrease in the moisture content of the yogurt during storage periods which affects the equilibrium among the other components, including proteins, fat and ash. Results revealed that the addition of thyme alcoholic and aqueous extracts did not influence significantly $(p<0.05)$ on protein content of the manufactured yogurt.This finding disagreed with the finding of Lee et al. (2016) who reported that adding Inula britannica flower extract in a Cheddarlike cheese affected positively on increasing the total protein compared to the control sample. Also, disagreed with Kucukoner and Tarakci (2003) who attributed the significant higher protein content of the manufactured yogurt to marmalade and grape molasses addition compared to the control.

The fat percentage of yogurt treatments indicated in table (1) showed that the fat percentage was low in the plain yogurt $(0.178 \%)$ and this low percentage is attributed to the low-fat content of skimmed milk that used in manufacturing the plain yogurt. The percentages of fat for (TCEY) and (TAEY) were $0.184 \%$ and $0.177 \%$ respectively. These results were close to Ihemeje et al. (2015) findings which was $1.80 \%$ in flavored yogurt, this corresponds with Mahmood et al. (2008) who reported that non-fat yogurt could be produced, but in general, the yogurt's fat level depends on milk's oil content, whether full cream or skimmed milk will have fat content in region of $4 \%$ (or slightly above) (Ihemeje et al., 2015). While during the storage periods, there was an increase in yogurt fat percentage of all treatments. The fat percentages in (PY), (TCEY) and (TAEY) after 28 days of storage were $0.32 \%$, $0.36 \%$ and $0.326 \%$, respectively. (TCEY) was nonsignificantly $(p<0.05)$ compared to the other two treatments. The reason for the relative increase in the percentage of fat in (TCEY) compared to (PY) and (TAEY) is attributed to the presence of a percentage of oil in the thyme alcoholic extract. Non-significant differences $(p<0.05)$ were found among yogurt treatments in fat content when adding thyme alcoholic and aqueous extracts to the manufactured yogurt compared to the plain 
Table 2. Microbial content of LAB, Coliform bacteria and yeast \& mold log (cfu/ml) of (PY), (TCEY) and (TAEY) during storage periods

\begin{tabular}{|c|c|c|c|c|c|c|}
\hline \multirow[b]{2}{*}{ Properties } & \multirow[b]{2}{*}{ Treatment } & \multicolumn{5}{|c|}{ Storage periods (day) } \\
\hline & & 0 & 7 & 14 & 21 & 28 \\
\hline \multirow[t]{3}{*}{ LAB } & Plain yogurt & 7.33 & 7.38 & 7.41 & 7.4 & 7.38 \\
\hline & Thyme alcoholic extract yogurt & 7.32 & 7.34 & 7.37 & 7.35 & 7.31 \\
\hline & Thyme aqueous extract yogurt & 7.3 & 7.33 & 7.36 & 7.35 & 7.32 \\
\hline \multirow[t]{3}{*}{ Coliform } & Plain yogurt & Nil & Nil & 0.3 & 0.47 & 0.69 \\
\hline & Thyme alcoholic extract yogurt & $\mathrm{Nil}$ & $\mathrm{Nil}$ & Nil & Nil & $\mathrm{Nil}$ \\
\hline & Thyme aqueous extract yogurt & Nil & $\mathrm{Nil}$ & Nil & Nil & $\mathrm{Nil}$ \\
\hline \multirow[t]{3}{*}{ Yeast \& Mold } & Plain yogurt & Nil & $\mathrm{Nil}$ & Nil & 0.6 & 0.77 \\
\hline & Thyme alcoholic extract yogurt & Nil & Nil & Nil & Nil & $\mathrm{Nil}$ \\
\hline & Thyme aqueous extract yogurt & $\mathrm{Nil}$ & $\mathrm{Nil}$ & $\mathrm{Nil}$ & Nil & $\mathrm{Nil}$ \\
\hline
\end{tabular}

$L S D=0.032(p<0.05)$

yogurt. This finding is in line with Kucukoner and Tarakci (2003) who illustrated that there were no significant differences in fat content of the yogurt contained fruit additives compared to the plain yogurt. Contrary, significant differences were found in fat content of yoghurt with different fruitflavors compared to the plain yogurt (Tarakçi and Kucukoner, 2003).

The ash percentage of (PY), (TCEY) and (TAEY) shown in table (1) were $0.58 \%, 0.54 \%$ and $0.57 \%$, respectively without any significant differences $(p<0.05)$, and this result was less than ash content of the fortified yogurt with different kind of juices which was $0.71 \%$ (Hossain et al., 2012). Result was close to Ihemeje et al., (2015)who found that ash content of flavored yogurt was (0.44\%). During the storage periods, there was an increase in yogurt ash percentage of all treatments. The ash percentage after 28 days of storage were $0.71 \%, 0.72 \%$ and $0.71 \%$, respectively without any significant differences $(p<0.05)$, and this in consistent with Aziznia et al., (2008) who found out a high ash content in the yogurt manufactured from skimmed milk and this is due to the composition of milk used in yogurt manufacturing, where the removal of fat increased the rates of both moisture and protein, and the high moisture content may cause an increase in the amount of dissolved mineral salts. Ash content have not been affected by the addition of thyme alcoholic and aqueous extracts compared to the plain yogurt. In contrast to this, adding different flavor additives to yogurt affected significantly on ash content compared to the plain yogurt (Tarakçi and Kucukoner, 2003).

Table (2) shows LAB, coliform bacteria and yeast \& mold content in (PY), (TCEY) and (TAEY) during storage periods. At zero time, there was nearly an equal non-significant $(p<0.05)$ content of LAB for all treatments $(7.33,7.32$ and 7.30) $\log (\mathrm{cfu} / \mathrm{ml})$, respectively, and increased gradually till the $21^{\text {st }}$ day and reduced after that to reach at day 28 to $(7.38,7.31$ and 7.32$) \log$ (cfu/ml), respectively. There was a significant difference $(p<0.05)$ between (PY) and the other two treatments, and this means that there was no significant effect for the extracts on LAB count in yogurt treated samples. The study results are in consistent with Azizkhani and Tooryan (2016) who found that the presence of basil or peppermint didn't affect on LAB content at zero time compared to plain yogurt, while the presence of thyme (zataria) essential oil in yogurt led to lower LAB content, and this may be attributed to thyme (zataria) essential oil components (more than $70 \%$ carvacrol) with a great inhibitory effect on Grampositive bacteria. Thus, thyme (zataria) considered as a strong antimicrobial (Zomorodian et al., 2011). On contrast, Joung et al. (2016) who found that plant extract supplementation enhanced the viability of LAB of the starter. Also (Suliman et al., 2019) indicated that the addition of cinnamon herb improved $L A B$ availability to reach acceptable levels. The increase in LAB content during study 
Table 3. Titratable acidity and pH of plain yogurt, thyme alcoholic extract yogurt and thyme aqueous extract yogurt

\begin{tabular}{|c|c|c|c|c|c|c|}
\hline \multirow[b]{2}{*}{ Treatments } & \multirow[b]{2}{*}{ Indicator } & \multicolumn{5}{|c|}{ Storage Periods (Day) } \\
\hline & & 0 & 7 & 14 & 21 & 28 \\
\hline \multirow[t]{2}{*}{ Plain Yogurt } & $\mathrm{pH}$ & 4.52 & 4.46 & 4.37 & 4.3 & 4.24 \\
\hline & Titratable acidity & 0.94 & 0.98 & 1.08 & 1.18 & 1.28 \\
\hline Thyme alcoholic & $\mathrm{pH}$ & 4.56 & 4.52 & 4.46 & 4.38 & 4.31 \\
\hline extract yogurt & Titratable acidity & 0.9 & 0.93 & 0.97 & 1.04 & 1.17 \\
\hline Thyme aqueous & $\mathrm{pH}$ & 4.56 & 4.51 & 4.42 & 4.34 & 4.29 \\
\hline extract yogurt & Titratable acidity & 0.9 & 0.95 & 1.01 & 1.12 & 1.2 \\
\hline
\end{tabular}

$\operatorname{LSD}=0.048(p<0.05)$

periods was obvious on $\mathrm{pH}$ reduction recorded in all yogurt treatments (Azizkhani and Tooryan, 2016).

For coliform and yeast \& mold content, there wasn't any growth during all study periods in (TCEY) and (TAEY) while there was a growth in (PY) treatment after 14 day for coliform and after 21 day for yeast $\&$ mold as shown in table (2). The reason behind the low content of coliform and yeast \& mold is thymol components, since thymol is the major active compound of thyme which exerts its antimicrobial activity by binding to membrane proteins (hydrophobic and hydrogen bonding) and changing the membrane permeability (Burt, 2004). Thymol decreases $E$. coli content of intracellular adenosine triphosphate (ATP) and increases extracellular ATP which then could disrupt the plasma membranes function (Tiwari et al., 2009). Also, thymol was proved to have antimicrobial activity against Gram-positive and Gram-negative bacteria (Burt, 2004). The absence of coliform and yeast \& mold from the two treated yogurt treatments could be due to the microbial action of phytochemicals compounds such as flavonoids and phenolic that exist in thyme extracts. This finding in line with Suliman et al., (2019) who reported that coliform bacteria and $E$. coli absence in treated samples for the antimicrobial action of C. cassia resulting from its phytochemicals composition.

Table (3) shows the $\mathrm{pH}$ values of (PY), (TCEY) and (TAEY) treatments. It is noted that the $\mathrm{pH}$ values in $(P Y)$ reduced significantly $(\mathrm{p}<0.05)$ compared to (TCEY) and (TAEY) after 28 day of storage periods and this may be attributed to the effect of alcoholic and aqueous extracts in (TCEY) and (TAEY) treatments on the growth of microorganisms and subsequently on $\mathrm{pH}$ values.
Study results came in agreement with Azizkhani and Tooryan (2016) who reported that the $\mathrm{pH}$ value of plain yogurt was close to essential oil treated yogurts, and there were significant differences ( $p$ $<0.05$ ) among treatments during storage periods. Study results came in line with Joung et al. (2016) who found that the $\mathrm{pH}$ values of all yogurt treatments decreased during the first 14 day of storage and then decreased again from day 21 to day 28 , The reason behind $\mathrm{pH}$ reduction during storage could be because of lactic acid conversion into lactose, storage duration, starter culture composition and temperature of fermentation (Singh et al., 2011). Alcoholic and aqueous extracts yogurt $\mathrm{pH}$ didn't affect significantly by adding thyme extracts and this may be attributed to the action of thyme extracts which restricted the bacterial growth of yogurt and subsequently kept its $\mathrm{pH}$ higher from the $\mathrm{pH}$ of control treatment. Same result by Joung et al., (2016) who reported that supplementation yogurt with plant extracts did not affect the initial $\mathrm{pH}$. Nevertheless, the $\mathrm{pH}$ values of all yogurt treatments during the entire storage periods are acceptable from the perspective of product quality. In same line with this finding, Suliman et al., (2019) indicated that cinnamon powder addition may help in stabilizing yogurt $\mathrm{pH}$.

The titratable acidity results (calculated based on lactic acid) shown in table (3) for all yogurt treatments. The titratable acidity at zero time for (PY), (TCEY) and (TAEY) were 0.94, 0.90 and 0.90 without any significant differences $(p<0.05)$, and reached $1.28,1.17$ and 1.2 , respectively. It was significant $(p<0.05)$ for (PY) compared to (TCEY) and (TAEY). This result is in contrast with Hossain et al. (2012) who reported that titratable acidity 
Table 4. Sensory evaluation of plain yogurt, thyme alcoholic extract yogurt and thyme aqueous extract yogurt

\begin{tabular}{lllllll}
\hline & & \multicolumn{5}{c}{ Storage Periods (Day } \\
\cline { 2 - 6 } Treatments & Ingredients \% & 0 & 7 & 14 & 21 & 28 \\
\hline \multirow{2}{*}{ Plain Yogurt } & Taste and flavor (45) & 43 & 43 & 40 & 35 & 31 \\
& Textures (30) & 29 & 28 & 26 & 25 & 25 \\
& Acidity (15) & 15 & 14 & 13 & 10 & 9 \\
Thyme alcoholic & General acceptance (10) & 9 & 8 & 8 & 7 & 6 \\
extract yogurt & Taste and flavor (45) & 42 & 41 & 41 & 40 & 40 \\
& Textures (30) & 30 & 29 & 29 & 28 & 28 \\
Thyme aqueous & Acidity (15) & 14 & 13 & 12 & 12 & 12 \\
extract yogurt & General acceptance (10) & 10 & 9 & 9 & 9 & 8 \\
& Texte and flavor (45) & 43 & 42 & 40 & 39 & 39 \\
& Acidity (15) & 30 & 28 & 27 & 27 & 26 \\
& General acceptance 10 & 14 & 13 & 12 & 11 & 11 \\
& & 10 & 9 & 8 & 8 & 7 \\
\hline
\end{tabular}

$\operatorname{LSD}=0.17(p<0.05)$

of yogurt fortified with different kinds of juices was 0.66 , and it was close to Matter et al. (2016) who reported that control and fruit yogurts acidity ranged from (0.886-1.085\%) at first day to (1.10$1.72-\%)$ at the tenth day of cold storage, and this increase in fruit yogurt acidity was because of the growth of lactic acid bacteria and producing of lactic acid. The titratable acidity increasing within storage periods could be attributed to lactic acid bacteria activity used in yogurt manufacturing. It was reported previously that lactose converted into lactic acid by the action of lactic acid bacteria and thereby increasing the fermented dairy foods acidity (Kumari et al., 2015). The TA of alcoholic and aqueous extracts yogurt didn't affect significantly by the addition of thyme extracts compared to plain yogurt TA, and this may be due to thyme extracts activity which reduced the growth of yogurt bacteria and subsequently reduced the accumulation of lactic acid produced by these bacteria compared to control yogurt. This finding was the same as the finding of Joung et al., (2016) who reported that supplementing yogurt with plant extracts did not affect on the TA. The TA of yogurt treatments increased due to $\mathrm{pH}$ decreasing, so the restricted $\mathrm{pH}$ of thyme extracts yogurt treatments kept the TA values lower that the TA of plain yogurt. Same result found by Suliman et al., (2019) who reported that titratable acidity of cinnamon treated yogurt affected by cinnamon addition which affected on $\mathrm{pH}$ slight increasing and subsequently on slight lowering of TA of the treated yogurt comparing with the plain yogurt.

The sensory characteristics of dairy products play an important role in consumer acceptance. Table (4) shows the sensory evaluation results of (PY), (TCEY) and (TAEY). The results showed that (TCEY) was more acceptable significantly $(p<0.05)$ compared to the other two treatments during the different storage periods. The taste and flavor of (PY) began to evolve and became unlike the two other treatments gradually during increasing the storage periods due to the development of acidity and this change in taste and acidic flavor attributed to the increase in the proteolytic bacteria numbers that break down proteins into short-chain peptides by proteolytic enzymes produced by these bacteria. Lactic acid bacteria are responsible for the development of the acidity and $\mathrm{pH}$ into a desirable limit during the progress of storage periods.

(TCEY) flavor was better than (TAEY) flavor due to the effect of thyme oil on microorganism's growth and activity which may allow to keep desired flavor and test. The superiority of (TCEY) followed by (TAEY) and (PY) may be attributed to flavor compounds' high level such as acetoin, acetaldehyde and diacetyl. (PY) was the lower in its acceptability scores and this may be due to the activity of its bacterial content and subsequently accumulation of organic acids which affected negatively on its acceptability scores. 
This corresponded with Joung et al. (2016) who indicated that high amount of acetic acid in plain yogurt may affects negatively on its taste and overall acceptance.

For the texture characteristics, (TCEY) and (TAEY) exceeded (PY). For the acidity characteristic, there were slight changes among (PY), (TCEY) and (TAEY) with the superiority of (TCEY) during different storage periods.

Supplemented yogurts with plant extracts reported previously to have more acceptable organoleptic property compared to plain yogurt. The presence of plant extracts improves yogurt organoleptic property through complementing sourness by increasing bitterness and increasing the favored flavor and texture. So, yogurt may become a potential good carrier for plant extract (Joung et al., 2016). On contrast, Cinnamon herb addition to yogurt resulted as the most undesirable in overall taste yogurt compared to the plain yogurt and the other samples Yadav and Shukla (2014).

\section{CONCLUSIONS}

Yogurt supplementation with thyme extracts was successfully manufactured with viable $L A B$ counts, up to the acceptable range and appropriate chemical composition during 28 days of study period compared to (PY). It is obvious to note that the survival of $L A B$ in yogurt treatments was higher in (PY) compared to the supplemented yogurts. Also, supplemented yogurt treatments showed inhibitory effect against coliform and yeast \& mold compared to (PY). The effectiveness of these thyme yogurt extracts to inhibit the growth of coliform, yeast \& mold and restricted LAB growth, may affected on keeping the $\mathrm{pH}$ of supplemented yogurts higher than the (PY) and the titratable acidity of supplemented yogurts lower that the (PY). Both supplemented yogurts were more acceptable regarding the sensory characteristics. So, incorporating the healthful ingredients into dairy products is needed for manufacturers considering. Therefore, the adding of thyme extracts to yogurt is recommended, as this addition has the potential to be further developed for consumers as a functional yogurt with desirable properties and longer shelf life.

\section{ACKNOWLEDGMENTS}

None.

\section{CONFLICT OF INTEREST}

The authors declare that there is no conflict of interest.

\section{AUTHORS' CONTRIBUTIONS}

All authors Conceived and designed the analysis and collected the date while Al-Shawi S. G. Performed the analysis and wrote the paper. All authors listed have made a substantial, direct and intellectual contribution to the work, and approved it for publication.

\section{FUNDING}

None.

\section{ETHICS STATEMENT}

This article does not contain any studies with human participants or animals performed by any of the authors.

\section{DATA AVAILABILITY}

All datasets generated or analyzed during this study are included in the manuscript

\section{REFERENCES}

1. Akarca G, Caglar, A, Tomar O. The effects spicing on quality of mozzarella cheese. Mljekarstvo: casopis za unaprjedenje proizvodnje i prerade mlijeka, 2016;66(2):112-121.

2. Association of Official Agricultural Chemists A.O.A.C. Official Methods of Analysis of AOAC International, 18th ed. Maryland: AOAC International, 2005.

3. Association of Official Analytical Chemists A.O.A.C. Official Methods of Analysis 16th ed. Association of Official Analytical Chemists International Arlington, Virginia, U.S.A. 2008.

4. Aygun O, Aslantas O, Oner S. A survey on the microbiological quality of Carra, a traditional Turkish cheese. Journal of Food Engineering , 2005;66(3):401404. https://doi.org/10.1016/j.jfoodeng.2004.04.013

5. Azizkhani M, Tooryan F. Antimicrobial activities of probiotic yogurts flavored with peppermint, basil, and zataria against Escherichia coli and Listeria monocytogenes. Journal of Food Quality and Hazards Control. 2016;3(3):79-86.

6. Aziznia S, Khosrowshahi A, Madadlou A, Rahimi J. Whey protein concentrate and gum tragacanth as fat replacers in nonfat yogurt: chemical, physical, and microstructural properties. Journal of Dairy Science. 2008;91(7):2545-2552. https://doi.org/10.3168/ jds.2007-0875 
7. Basch E, Ulbricht C, Hammerness P, Bevins A, Sollars D. Thyme (Thymus vulgaris L.), thymol. Journal of Herbal Pharmacotherapy. 2004;4(1):49-67. https:// doi.org/10.1080/J157v04n01_07

8. Burt S. Essential oils: their antibacterial properties and potential applications in foods-a review. International Journal of Food Microbiology. 2004;94(3):223-253. https://doi.org/10.1016/j.ijfoodmicro.2004.03.022

9. Caleja C, Barros L, Antonio AL, Carocho M, Oliveira $M B P$, Ferreira IC. Fortification of yogurts with different antioxidant preservatives: A comparative study between natural and synthetic additives. Food Chemistry. 2016;210:262-268. https://doi. org/10.1016/j.foodchem.2016.04.114

10. Carlsen MH, Halvorsen BL, Holte K, Bohn SK, Dragland $S$, Sampson L, Willey C, Senoo H, Umezono Y, Sanada C, Barikmo I, Berhe N, Willett WC, Phillips KM, Jacobs Jr DR, Blomhoff R. The total antioxidant content of more than 3100 foods, beverages, spices, herbs and supplements used worldwide. Nutrition Journal. 2010;9(1):3. https://doi.org/10.1186/1475-2891-9-3

11. Cornara L, La Rocca A, Marsili S, Mariotti MG. Traditional uses of plants in the Eastern Riviera (Liguria, Italy). J Ethnopharmacol. 2009;125(1):16-30. https:// doi.org/10.1016/j.jep.2009.06.021

12. Dorman HJD, Deans SG. Antimicrobial agents from plants: antibacterial activity of plant volatile oils. Journal of Applied Microbiology. 2000;88(2):308-316. https:// doi.org/10.1046/j.1365-2672.2000.00969.x

13. Duke JA. Database of phytochemical constituents of GRAS herbs and other economic plants. CRC Press, 1992.

14. Egan H, Kirk RS, Sawyer R. Pearson Chemical Analysis of Food. 8th ed., Reprinted by Longman Scientific and Technical, UK, 1988.

15. Elmastas M Cinkilic, S, Aboul-Enein HY. Antioxidant capacity and determination of total phenolic compounds in daisy (Matricaria chamomilla), Fam. Asteraceae). World Journal of Analytical Chemistry. 2015;3:9-14.

16. Gahruie HH, Eskandari MH, Mesbahi G, Hanifpour MA. Scientific and technical aspects of yogurt fortification: A review. Food Science and Human Wellness. 2015;4(1):1-8. https://doi.org/10.1016/j. fshw.2015.03.002

17. Gammariello D, Di Giulio S, Conte A, Del Nobile MA. Effects of natural compounds on microbial safety and sensory quality of Fior di Latte cheese, a typical Italian cheese. Journal of Dairy Science. 2008;91(11):41384146. https://doi.org/10.3168/jds.2008-1146

18. Gillett M. Growing and Using Thyme: Storey's Country Wisdom Bulletin A-180. storey publishing, 1998.

19. Ihemeje A, Nwachukwu CN, Ekwe CC. Production and quality evaluation of flavoured yoghurts using carrot, pineapple, and spiced yoghurts using ginger and pepper fruit. African Journal of Food Science. 2015;9(3):163-169. https://doi.org/10.5897/ AJFS2014.1244

20. Joung JY, Lee JY, Ha YS, Shin YK, Kim Y, Kim SH, Oh NS. Enhanced microbial, functional and sensory properties of herbal yogurt fermented with Korean traditional plant extracts. Korean Journal for Food Science of
Animal Resources. 2016;36(1):90-99. https://doi. org/10.5851/kosfa.2016.36.1.90

21. Kucuknoer, E, Tarakci Z. Influence of different fruit additives on some properties of stirred yoghurt during storage. Yuzuncu Yil Universitesi Tarim Bilimleri Dergisi. 2003;13(2):97-101.

22. Kumari AGIP, Ranadheera CS, Prasanna PHP, Senevirathne ND, Vidanarachchi JK. Development of a rice incorporated synbiotic yogurt with low retrogradation properties. International Food Research Journal. 2015;22(5).

23. Lee NK, Jeewanthi RKC, Park EH, Paik HD. Physicochemical and antioxidant properties of Cheddar-type cheese fortified with Inula britannica extract. Journal of Dairy Science. 2016;99(1):83-88. https://doi.org/10.3168/jds.2015-9935

24. Madadlou A, Khosroshahi A, Mousavi ME. Rheology, microstructure, and functionality of low-fat Iranian white cheese made with different concentrations of rennet. Journal of Dairy Science. 2005;88(9):3052-3062. https://doi.org/10.3168/jds.S0022-0302(05)72986-6

25. Mahmood A, Abbas N, Gilani AH. Quality of stirred buffalo milk yogurt blended with apple and banana fruits. Pak J Agric Sci. 2008;45(2):275-279.

26. Matter AA, Mahmoud EAM, Zidan SZ. Fruit flavored yogurt: Chemical, functional and rheological properties. International Journal of Environmental \& Agriculture Res.. 2016;2(5):57-66.

27. Mossa JS. Medical Plants of Saudi Arabia, published by king Saudi university libraries, Riyadh, 1987; 244.

28. Guler-Akin MB. The effects of different incubation temperatures on the acetaldehyde content and viable bacteria counts of bio-yogurt made from ewe's milk. International Journal of Dairy Technology. 2005;58(3):174-179. https://doi.org/10.1111/j.14710307.2005.00209.x

29. Guler-Akin MB, Nelson JA, Trout GM. Judging dairy product. The Olsen Publishing Co., Milwaukee, Wis. 53212,USA, 1964.

30. O'connell JE, Fox PF. Significance and applications of phenolic compounds in the production and quality of milk and dairy products: a review. International Dairy Journal. 2001;11(3):103-120. https://doi.org/10.1016/ S0958-6946(01)00033-4

31. Case $\mathrm{OH}$. An assessment of medicinal hemp plant extracts as natural antibiotic and immune modulation phytotherapies (Doctoral dissertation, University of the Western Cape), 2005.

32. Qureshi AM, Hassan SY, Sulariya AM, Rashid AA. Preparation and nutritional evaluation of garlic based yogurt. Science International, Lahore. 2011;23(1):5962.

33. Preedy VR, Srirajaskanthan R, Patel VB. Handbook of food fortification and health. From Concepts to Public Health Applications. 2013. https://doi. org/10.1007/978-1-4614-7076-2

34. Salim-ur-Rehman SH, Nawaz H, Ahmad MM, Murtaza MA, Rizvi AJ. Inhibitory effect of citrus peel essential oils on the microbial growth of bread. Pakistan Journal of Nutrition. 2007;6(6):558-561. https://doi. org/10.3923/pjn.2007.558.561

35. Singh G, Kapoor IPS, Singh P. Effect of volatile oil and 
oleoresin of anise on the shelf life of yogurt. Journal of Food Processing and Preservation. 2011;35(6):778-783. https://doi.org/10.1111/j.1745-4549.2011.00528.x

36. Skandamis PN, Nychas GJ. Effect of oregano essential oil on microbiological and physico-chemical attributes of minced meat stored in air and modified atmospheres. Journal of Applied Microbiology. 2001;91(6):1011-1022. https://doi.org/10.1046/ j.1365-2672.2001.01467.x

37. SPSS. (SPSS) statistical package for window ver. 2009;17. Chicago: SPSS, Inc.

38. Tarakci Z, Kucukoner E. Physical, chemical, microbiological and sensory characteristics of some fruit-flavored yoghurt. YYU Vet Fak Derg. 2003;14(2):10-14.

39. Suliman AH, Ahmed KE, Mohamed BE, Babiker EE. Potential of Cinnamon (Cinnamomum Cassia) as an Anti-Oxidative and Anti-Microbial Agent in Sudanese Yoghurt (Zabadi). Journal of Dairy and Veterinary Sciences. 2019;12(2):1-8: 555833. https://doi. org/10.19080/JDVS.2019.12.555833

40. Tiwari BK, Valdramidis VP, O'Donnell CP Muthukumarappan K, Bourke P, Cullen PJ. Application of natural antimicrobials for food preservation. Journal of Agricultural and Food Chemistry. 2009;57(14):59876000. https://doi.org/10.1021/jf900668n

41. Tsigarida E, Skandamis P, Nychas GJ. Behaviour of Listeria monocytogenes and autochthonous flora on meat stored under aerobic, vacuum and modified atmosphere packaging conditions with or without the presence of oregano essential oil at $5 \mathrm{C}$. Journal of Applied Microbiology. 2000;89(6):901-909. https:// doi.org/10.1046/j.1365-2672.2000.01170.x

42. Uaboi-Egbenni PO, Okolie PN, Akintunde TI, BisiJohnson O, Enwe L, Bessong PO. Proximate analysis and microbiological quality of cheese produced from raw cow milk obtained from Fulani settlement in Ogun state Nigeria, using lactic acid bacteria and extract from Sodom apple leaf (Calotropis procera). Pakistan Journal of Nutrition. 2010;9(9):920-925. https://doi. org/10.3923/pjn.2010.920.925

43. Van Haute S, Raes K, Van Der Meeren P, Sampers I. The effect of cinnamon, oregano and thyme essential oils in marinade on the microbial shelf life of fish and meat products. Food Control. 2016;68:30-39. https:// doi.org/10.1016/j.foodcont.2016.03.025

44. Yadav K, Shukla S. Microbiological, physicochemical analysis and sensory evaluation of herbal yogurt. The Pharma Innovation. 2014;3(10, Part A):1.

45. Zarzuelo A, Crespo E. "The medicinal and nonmedicinal uses of thyme," in Thyme: The Genus Thymus. Medicinal and Aromatic Plants-Industrial Profiles, E. Stahl-Biskup and F. Saez, Eds. 2002;263292, Taylor \& Francis, New York, NY, USA.

46. Zomorodian K, Saharkhiz MJ, Rahimi MJ, et al. Chemical composition and antimicrobial activities of the essential oils from three ecotypes of Zataria multiflora. Pharmacognosy Magazine. 2011;7(25):5359. https://doi.org/10.4103/0973-1296.75902 